\title{
Recenzja monografii Kamila Szpyta Obrót dobrami wirtualnymi w grach komputerowych. Studium cywilnoprawne
}

\author{
Mateusz Mądel \\ Okręgowa Izba Radców Prawnych w Krakowie \\ mateusz.madel@gmail.com | ORCID: 0000-0001-6252-6903 \\ DOI: 10.14746/hl.2019.12.13 | received: 31.12.2017 | accepted: 24.11.2019
}

Dla konserwatywnych cywilistów podjęte przez autora monografii zagadnienia obrotu dobrami wirtualnymi, który odbywa się w ramach gier komputerowych, mogą wydawać się problematyką ,wirtualną”. Niemniej jednak w miarę rozwoju Internetu i nowych technologii oraz w miarę wzrostu popularności sieciowej rozrywki wątpliwości związane $\mathrm{z}$ aktualnością przepisów zaczynają dotykać różnych dziedzin prawa. Chodzi już nie tylko o problemy na gruncie prawa karnego (Kulesza, Kulesza, 2009, s. 23 n.; Czaplicki, 2011, s. 399 n.; Kulesza, 2013, s. 297 n.; Jagiełło, 2014, s. 76 n.), autorskiego (Cień, 2016, s.31; Matusiak, 2014, s. 142), czy podatkowego (Camp, 2007, s. 2-3), ale również - a może zwłaszcza - cywilnego (Załucki, 2014, s. 234 n.; Chałubińska-Jentkiewicz, Karpiuk, 2015, s. 319 n.; Szpyt, 2014, s. 216 n.; Rekies, Żarski, 2013, s. 120 n.; Jagielska, Rauch, 2016, s. 235 n.). O realności zagadnień opisywanych w pracy można się przekonać już po lekturze przedmowy, w której autor podaje zarejestrowane przykłady obrotu wirtualnymi dobrami wraz z wartościami transakcji. Okazuje 
się, że wirtualny miecz, element zbroi, cała postać lub stacja kosmiczna nabywane są za gotówkę, a kwota sięga nieraz tysięcy dolarów amerykańskich. Należy też podkreślić, że stronami obrotu bywają także obywatele Polski ${ }^{1}$, dlatego problemy prawne, jakie mogą się pojawić w przypadku obrotu tego rodzaju dobrami, są aktualne również na gruncie rodzimych uregulowań prawnych.

Zagadnienia wybrane przez autora już uprzednio stały się przedmiotem zainteresowania przedstawicieli nauk prawnych, czego przejawem były publikacje zbiorowe, artykuły naukowe i wystąpienia konferencyjne, w których podejmowano wysiłki zmierzające rozwiązania pojedynczych problemów z zakresu zarówno obrotu dobrami wirtualnymi, jak i samych gier komputerowych. Pomimo formułowania niekiedy szczegółowych propozycji i diagnozowania trudności w publikacjach tych zwracano uwagę na konieczność prowadzenia dalszych pogłębionych badań. Niemniej jednak do tej pory nie ukazała się praca próbująca kompleksowo zdefiniować wspomniane problemy, przytoczyć poglądy prezentowane w literaturze i w miarę możliwości rozstrzygnąć wątpliwości pojawiające się w kontekście obrotu dobrami omawianego typu.

Recenzowana publikacja składa się z przedmowy, wykazu literatury, bibliografii oraz sześciu rozdziałów. W przedmowie opisano podstawowe zagadnienia i zarysowano wątpliwości związane z obrotem dobrami wirtualnymi. Określono tam również główną tezę i hipotezy, a także wykorzystaną w pracy metodologię badań.

W pierwszym rozdziale uwaga została skupiona na kwestiach definicyjnych, dotyczących w szczególności takich pojęć jak gra komputerowa, świat wirtualny, „magiczny krąg”, gracz oraz dobro wirtualne. Dokonano również charakterystyki podmiotów uczestniczących w obrocie oraz wyjaśniono podstawowe zjawiska i mechanizmy właściwe dla gier komputerowych.

W drugim rozdziale podjęto próbę rozwiązania pojawiającego się często problemu statusu dobra wirtualnego na gruncie obowiązujących przepisów prawa, w szczególności w kontekście norm systemu praw

1 Aby się o tym przekonać, wystarczy wpisać odpowiednie sformułowanie w wyszukiwarce na popularnych w Polsce portalach aukcyjnych. Wprowadzając przykładowo „World of Warcraft gold”, otrzymamy kilkanaście ofert dotyczących sprzedaży wirtualnej waluty w grze World of Warcraft. 
człowieka, a także przepisów Konstytucji $\mathrm{RP}^{2}$, Kodeksu cywilnego ${ }^{3}$, ustawy o prawach konsumenta ${ }^{4}$ oraz na gruncie prawa własności intelektualnej.

W rozdziale trzecim wskazano istniejące i możliwe do wykorzystania instrumenty obrotu dobrami wirtualnymi w grach komputerowych oraz używania takich dóbr. Rozważono potencjał zastosowania umowy cesji, umowy o świadczenie usług oraz umowy sublicencji, a także użytkowania i dzierżawy.

Rozdział czwarty skupia uwagę czytelnika na problemach odpowiedzialności za naruszenie zobowiązania w obrocie dobrami wirtualnymi, jaka może powstać $\mathrm{w}$ ramach gier komputerowych. Autor przywołuje w tym miejscu wiele przykładów na okoliczności powodujące niekiedy odpowiedzialność jednej ze stron kontraktu.

Rozdział piąty dotyczy kwestii ustalenia jurysdykcji sądów i prawa właściwego dla sporów mogących powstać w wyniku obrotu dobrami wirtualnymi w grach komputerowych, a także alternatywnych metod rozstrzygania sporów.

Rozdział szósty zawiera propozycje de lege ferenda. Autor dokonuje oceny istniejących uregulowań legislacyjnych, krytycznie analizuje dotychczasowe sugestie przedstawicieli nauk prawnych oraz formułuje wskazówki dotyczące przyszłych uregulowań, mające na celu racjonalizację obrotu dobrami wirtualnymi w kontekście kwestii poruszanych w pracy.

Ostatni rozdział - siódmy - stanowi zakończenie i podsumowanie rozważań przeprowadzonych w pracy.

Oceniając publikację od strony formalnej, należy wskazać, że została ona napisana starannym i przejrzystym językiem. Dostrzegalny jest indywidualny styl autora, który właściwie przeprowadził polemikę prawniczą. Praca zawiera szereg krytycznych uwag w zakresie dotychczasowych poglądów przedstawicieli nauk prawnych oraz propozycję własnych rozwiązań. Na uznanie zasługuje również uwzględnienie bogatej literatury, zarówno polskiej, jak i zagranicznej. W kilku miejscach znajdują się

2 Konstytucja Rzeczypospolitej Polskiej z 2 kwietnia 1997 (Dz.U. Nr 78, poz. 483).

3 Kodeks cywilny z 23 kwietnia 1964 (tj. z 9 lutego 2017; Dz.U. z 2017 r., poz. 459).

4 Ustawa o prawach konsumenta z 30 maja 2014 (tj. z 9 marca 2017; Dz.U. z 2017 r., poz. 683). 
drobne literówki (s. 210, 416), nie rzutują one jednak na ogólną - bardzo pozytywną - ocenę całości.

Jak to opisano powyżej, autor recenzowanej pracy porusza wiele zagadnień z zakresu szeroko pojętego prawa prywatnego w kontekście kłopotów, z jakimi mogą się spotkać uczestnicy obrotu dobrami wirtualnymi w grach komputerowych.

Należy zauważyć, że jeszcze kilkanaście lat temu poruszane w monografii problemy nie istniały, a obrót dobrami wirtualnymi na pewno nie był tak powszechny jak dziś. Ponadto ciągle pojawiają się nowe dobra tego rodzaju, i to nie tylko w ramach wirtualnych światów gier komputerowych. Ustawodawca, projektując Kodeks cywilny czy ustawę o prawie autorskim i prawach pokrewnych ${ }^{5}$, nie mógł przewidzieć, że uregulowanie tego typu zagadnień będzie w ogóle potrzebne. Niemniej jednak pomimo wielu nowelizacji wskazanych wyżej ustaw oraz ciągłego wprowadzania nowych regulacji do polskiego systemu prawnego obrót dobrami wirtualnymi nie spotkał się z zainteresowaniem ze strony ustawodawcy. $\mathrm{W}$ kontekście powyższego główne zadanie wynikające $\mathrm{z}$ wyboru tego właśnie tematu polega na dostrzeżeniu oraz dokonaniu próby zastosowania istniejących obecnie przepisów i klasycznych instytucji do nowych zagadnień, które pojawiły się w wyniku rozwoju technologii. W tym konkretnym przypadku - z uwagi na powstanie zaawansowanych gier komputerowych i rozwój Internetu.

Nowatorskość recenzowanej pracy polega na kompleksowym ujęciu możliwości funkcjonowania obrotu dobrami wirtualnymi na podstawie polskich przepisów prawa. Ze względu na wielość zagadnień poruszonych przez autora trudno omówić wszystkie wskazane w monografii koncepcje czy propozycje rozwiązania problemów zdiagnozowanych przez autora. W recenzji warto jednak przytoczyć te najciekawsze.

Na aprobatę zasługuje w szczególności świeże i nieszablonowe podejście badacza do instytucji, których funkcjonowanie zostało już - jak mogłoby się wydawać - dostatecznie wyjaśnione w doktrynie i utrwalone w świadomości prawników. Dlatego niebagatelne znaczenie mają $\mathrm{w}$ tym zakresie kwestie definicyjne. $\mathrm{Z}$ uwagi na podjętą tematykę autor

5 Ustawa o prawie autorskim i prawach pokrewnych z 4 lutego 1994 r. (tj. z 5 kwietnia 2017; Dz.U. z 2017 r., poz. 880). 
musiał wprowadzić do pracy szereg nowych pojęć, jakich znaczenia nie są ustalone w licznych przecież źródłach polskiego prawa. W ramach podjętego tematu niezbędna była zatem swoista transkrypcja potocznego i intuicyjnego rozumienia niektórych terminów na grunt języka prawnego i prawniczego w ten sposób, aby odbiorca publikacji mógł zrozumieć nomenklaturę powszechnie wykorzystywaną przez graczy. Ponadto konieczna okazała się również aktualizacja wielu nawet podstawowych definicji funkcjonujących w dyskursie - np. gry komputerowej (s. 12-13), awatara (s. 46), czy przedmiotu wirtualnego (s. 41). Dokonanie powyższego jest o tyle trudnym zadaniem, że aktualizowanie definicji albo w ogóle pierwotne definiowanie nowych zjawisk z zakresu nowych technologii wymaga zachowania tzw. technicznej neutralności. Pozwala to na utrzymanie aktualności omawianych pojęć przez dłuższy czas, co w przypadku zagadnień poruszanych przez autora nie jest prostym zadaniem. Wydaje się, że wprowadzone przez autora definicje nie mają szerokiego charakteru i spełniają powyższy postulat, trudno jednak już teraz ocenić ich aktualność w dłuższej perspektywie. Nie zmienia to jednak tego, że umiejętne i szczegółowe wyjaśnienie terminów wprowadzonych przez badacza do książki pozwala na zrozumienie poruszanych zagadnień prawnikowi, który nigdy nie miał styczności z grami komputerowymi.

Wśród wielu ciekawych rozwiązań na uwagę zasługuje chociażby koncepcja nowego dobra osobistego w postaci „przyjemności z gry” (s. 241), jaką można utracić, a także dokonanie szczegółowego rozróżnienia na dobra wirtualne dające się uznać za utwór w rozumieniu prawa autorskiego i znajdujące się poza zakresem tego pojęcia (s. 155 n.). Na pozytywną ocenę zasługuje również drobiazgowa analiza instrumentów de lege lata, jakie niosą potencjał wykorzystania do obrotu dobrami wirtualnymi. Rozważania dotyczą w szczególności potencjalnego zastosowania (w obrocie) umowy cesji, umowy o świadczenie usług lub innych umów nienazwanych, a także tych upoważniających do używania wirtualnych dóbr przy zastosowaniu umowy dzierżawy, użytkowania oraz sublicencji.

Niemniej jednak z uwagi na brak możliwości kompleksowego wykorzystania chociażby jednego z cywilnoprawnych instrumentów oraz na wiele wątpliwości tego dotyczących autor omawianej książki proponuje własną koncepcję regulacji de lege ferenda, która zakłada przede wszystkim stworzenie całościowej regulacji mającej za przedmiot dobra wirtualne. 
Zaproponowana przez Szpyta koncepcja zakłada powołanie nowego prawa bezwzględnego, opartego na prawie własności i wykorzystującego w ograniczonym zakresie prawa obligacyjne (s. 339). Zaproponowane rozwiązanie w zamyśle autora powinno odnosić się nie tylko do wirtualnych postaci oraz przedmiotów z gier komputerowych, ale również do innych dóbr wirtualnych (treści cyfrowych ${ }^{6}$ ), które funkcjonują w obrocie. Ponadto badacz postuluje, by nowa regulacja zawierała (zaproponowane również w treści pracy) przepisy dotyczące m.in. powstania i wygaśnięcia prawa, instrumentów przeniesienia własności przedmiotów wirtualnych oraz odpowiedzialności za wady dobra wirtualnego. Wszelkie powyższe propozycje swoją treścią zbliżają się do praw rzeczowych, które obecnie charakterystyczne są dla rzeczy w rozumieniu art. $45 \mathrm{kc}$.

Zdaniem autora recenzowanej monografii, tego rodzaju regulacje mogłyby zostać z powodzeniem wprowadzone do Kodeksu cywilnego, jak również w ramach zupełnie nowej ustawy. Pogląd ów należy zaaprobować co do zasady, ponieważ jest on niejako odzwierciedleniem postrzegania omawianych przez Szpyta dóbr przez społeczność graczy, którzy rozpatrują np. konto gry, wirtualny przedmiot czy awatara w kategoriach prawa własności. Oczywiście zaproponowana przez badacza koncepcja może okazać się nie do zaakceptowania przez tradycjonalistów. Nie zmienia to jednak faktu, że na tym niedostrzeganym przez prawodawcę gruncie istnieje potrzeba wprowadzenia nowych regulacji. A wykorzystanie w tym celu nowej koncepcji prawa bezwzględnego wydaje się słuszną drogą do uregulowania obrotu dobrami wirtualnymi.

Należy jednak wskazać pewne zastrzeżenie do zarysowanej tak propozycji. Mało prawdopodobne jest bowiem, aby w zakresie wprowadzenia takowej regulacji decydujący głos miał polski ustawodawca. Należy pamiętać, że wydawcami gier komputerowych w przeważającej większości są podmioty mające swoją siedzibę poza granicami kraju. Uchwalenie bezwzględnego prawa własności wirtualnej nie będzie przez nich

6 Definicja legalna treści cyfrowych została wprowadzona do polskiego systemu prawnego wraz z uchwaleniem ustawy z 30 maja 2014 o prawach konsumenta, która dokonuje w zakresie swojej regulacji wdrożenia dyrektywy Parlamentu Europejskiego i Rady 2011/83/UE z 25 października 2011 w sprawie praw konsumentów. Zgodnie $\mathrm{z}$ art. 2 pkt 5 ustawy o prawach konsumenta „treść cyfrowa” to dane wytwarzane i dostarczane w postaci cyfrowej (Bar, Klimas, 2016, s. 276-277; Szostek, 2014, s. 2). 
postrzegane pozytywnie, ponieważ spowoduje ograniczenie ich wpływu na wirtualny świat gry. Obecnie bowiem, jak zauważa sam Szpyt, regulaminy umów z wydawcami często ograniczają możliwość obrotu wirtualnymi dobrami lub całymi kontami gry komputerowej. Wprowadzenie zatem zaproponowanych regulacji jedynie na poziomie prawa krajowego może przyczynić się nie tylko do wykluczenia polskich graczy z możliwości uczestniczenia w rozgrywce, ale również do pominięcia ich przy rozpowszechnianiu nowych tytułów na rynku. Podobne zastrzeżenie formułuje się w kontekście zaostrzania prawa ochrony konsumentów. W nauce dotyczącej ten dziedziny przytomnie wskazuje się, że przesadne uprzywilejowanie owej grupy często prowadzi do pogorszenia się jej sytuacji z uwagi na ryzyko ograniczenia - przez zagranicznych przedsiębiorców - terytorialnego zasięgu prowadzenia działalności internetowej. W konsekwencji może to spowodować wykluczenie konsumentów danego kraju z globalnego rynku i usług, często przecież atrakcyjniejszych od propozycji przedsiębiorców rodzimych (Kocot, 2004, s. 404; Świerczyński, Kolasiński, 2016, s. 263). Dlatego, jak się wydaje, regulacje w tym zakresie winny być wprowadzone co najmniej na poziomie dyrektyw unijnych, aby nie pozbawić polskich graczy dostępu do najpopularniejszych wirtualnych światów gier komputerowych. Oczywiście do ustalenia konkretnego brzmienia ewentualnych przepisów w omawianej materii jeszcze daleka droga, niemniej jednak na uwagę zasługują wszystkie pojawiające się koncepcje, które w zamyśle mają wieść do normalizacji obrotu dobrami wirtualnymi. Dlatego niezmiernie ważna jest dyskusja nad ewentualnym kształtem przyszłych uregulowań.

Wydaje się, że recenzja publikacji naukowej powinna skupić się na ocenie tego, co w pracy jest zawarte, a nie tego, co autor pominął, ale należy zaznaczyć, że pomimo wielu walorów opisywanej monografii po lekturze całości nasuwa się również inne zastrzeżenie. Chodzi w szczególność o brak wzmianki na temat dalszego losu wirtualnych dóbr po śmierci gracza. Kodeksowe regulacje prawa spadkowego wydają się koniecznym elementem cywilnoprawnych rozważań, zwłaszcza gdy mowa o kompleksowym ujęciu problemów na gruncie prawa cywilnego. Należałoby rozważyć możliwość zaliczenia dóbr wirtualnych oraz innych cyfrowych treści związanych z grami komputerowymi do spadku po zmarłym graczu - w kontekście art. 922 kc. W ramach przypomnienia należy wskazać, 
że zgodnie z przywołanym przepisem w skład spadku po osobie zmarłej wchodzą cywilnoprawne prawa i obowiązki o charakterze majątkowym, które nie są ściśle związane z osobą spadkodawcy oraz nie przechodzą na oznaczone osoby, niezależnie od tego, czy są one spadkobiercami. O ile wstępna analiza może prowadzić do wniosku, że omawiane przez autora dobra wypełniają przesłankę cywilnoprawnego i majątkowego charakteru, o tyle dokonanie dalszych ustaleń może okazać się sporym wyzwaniem. Rozważania w tym zakresie rozrosłyby się zapewne na tyle, że w pełni zasługiwałyby na opisanie w kolejnej monografii. Autor słusznie zatem odsyła w tym zakresie do innych publikacji skupiających się na szczegółowych zagadnieniach dotyczących stosunków prawnych mortis causa (s. 97).

Należy stanowczo zaznaczyć, że powyższe uwagi mają charakter jedynie polemiczny i w żaden sposób nie umniejszają wartości recenzowanej publikacji. Praca stanowi bowiem nowatorskie i w zasadzie kompleksowe studium z zakresu obrotu dobrami wirtualnymi. Trzeba też wskazać, że recenzowana monografia jest uzupełnieniem pracy doktorskiej, która wygrała III Ogólnopolski Konkurs im. Profesora Zbigniewa Radwańskiego i została wyróżniona przez Wydział Prawa, Administracji i Stosunków Międzynarodowych Krakowskiej Akademii im. Andrzeja Frycza Modrzewskiego. Dodatkowo utwierdza to w przekonaniu, że omawiana praca zasługuje na wysoką ocenę $z$ uwagi na swoje walory teoretyczne i praktyczne.

Podsumowując, należy stwierdzić, że wątpliwości związane z obrotem wirtualnymi dobrami w grach komputerowych nie mogły pozostać bez komentarza w rodzimej literaturze. Ewoluują poglądy przedstawicieli nauk prawnych, postępuje rozwój gier komputerowych i internetu, a polski i unijny prawodawca nadal zwlekają z wypracowaniem kompleksowej regulacji problemów związanych nie tylko z obrotem dobrami w grach komputerowych, ale również $\mathrm{z}$ obrotem innymi dobrami wirtualnym. Recenzowana publikacja niewątpliwie wzbogaca naukę rodzimego prawa cywilnego. Dokonana przez Szpyta krytyczna analiza orzecznictwa oraz polskiej i zagranicznej literatury, a także nieoceniona wartość poznawcza przeprowadzonych wywodów utwierdzają w przekonaniu, że monografia jest pracą naukową na bardzo wysokim poziomie, dowodzącą erudycji jej autora i przybliżającą naukę prawa do wypracowania odpowiednich rozwiązań. 


\section{Literatura}

Bar, G., Klimas, D. (2016), Treść cyfrowa w obrocie konsumenckim. W: K. Flaga-Gieruszyńska, J. Gołaczyński, S. Szostek (red.), Media elektroniczne. Wspótczesne problemy prawne (s. 273-283). Warszawa: C. H. Beck.

Camp, B. T. (2007). The Play's the Thing: A Theory of Taxing Virtual Worlds. Hastings Law Journal, 59(1), 1-72.

Chałubińska-Jentkiewicz K., Karpiuk M. (2015) Prawo nowych technologii. Wybrane zagadnienia. Warszawa: Wolters Kluwer.

Cień, K. (2016). Odpowiedzialność z tytułu naruszenia prawa do wizerunku w Internecie. W: A. Niewęgłowski, M. Chrzanowski (red.), Internet a prawo autorskie (s. 31-39). Lublin: Uniwersytet Marii Curie-Skłodowskiej.

Czaplicki, K. (2011). Kradzież tożsamości w Internecie. W: G. Szpor (red.), Internet. Ochrona własności i bezpieczeństwa (s.399-407). Warszawa: C. H. Beck.

Jagielska, M. (2017). Dopuszczalność wyboru prawa w umowach z konsumentami zawieranych za pomocą wzorca umownego. W: M. Jagielska, E. Rott-Pietrzyk, M. Szpunar (red.), Rozprawy z prawa prywatnego. Księga jubileuszowa dedykowana Profesorowi Wojciechowi Popiołkowi (s. 71-78). Warszawa: Wolters Kluwer.

Jagielska, M., Rauch, I. (2016). Klauzule abuzywne w umowach standardowo zawieranych przez Internet. W: K. Flaga-Gieruszyńska, J. Gołaczyński, S. Szostek (red.), Media elektroniczne. Współczesne problemy prawne (s. 235-251) . Warszawa: C. H. Beck.

Jagiełło, D. (2014). Przestępstwa popełniane w świecie wirtualnym (tzw. virtual crime) a problemy wynikające z przyjęcia odpowiedniej kwalifikacji prawnej oraz możliwości dowodzenia ich znamion. Wrocławskie Studia Sądowe, 4(4), 76-88.

Kocot, W. J. (2004). Wpływ internetu na prawo umów. Warszawa: LexisNexis.

Kulesza, J. (2013). Prawnokarna ochrona wirtualnej własności? W: K. Grzybczyk (red.), Prawo w wirtualnych światach (s. 297-311). Warszawa: Difin.

Kulesza, J. Kulesza, J. (2009). Gra „Second Life” - wirtualny świat, realne przestępstwa? Prokuratura i Prawo, 15(3), 23-40. Online: <http://pk.gov. 
pl/wp-content/uploads/2013/12/561ecc24a36c7ad8b2a2408c8fbb12fd. doc>. Data dostępu: 8 października 2019.

Matusiak, I. (2014). Awatar jako przedmiot tzw. własności wirtualnej: powstanie, korzystanie i obrót - aspekt autorskoprawny, Wrocławskie Studia Sądowe, 4(4), 142-160.

Rekies, J., Żarski, M. (2013). Obrót wirtualnymi przedmiotami z MMORPG. Sweatshop, gold farming i real money trading. W: K. Grzybczyk (red.), Prawo w wirtualnych światach (s. 120-154. Warszawa: Difin.

Szostek, D. (2014). Problem treści cyfrowych w obrocie konsumenckim. Monitor Prawniczy, 17(4), 1289-1294. Online: <http://czasopisma.beck. $\mathrm{pl} /$ monitor-prawniczy/artykul/problem-tresci-cyfrowych-w-obrocie-konsumenckim>. Data dostępu: 8 października 2019.

Szpyt, K. (2014). Umowa „sprzedaży” dobra wirtualnego oraz konta na serwerze gry. Wrocławskie Studia Sądowe, 4(4), 216-234.

Świerczyński, M., Kolasiński M. (2016). Wybór prawa obcego w internetowych wzorcach umownych a ochrona konsumenta. W: K. Flaga-Gieruszyńska, J. Gołaczyński, D. Szostek (red.), Media elektroniczne. Wspótczesne problemy prawne (s. . Warszawa: C. H. Beck.

Załucki, M. (2014). „Facebook”, „Twitter”, „MySpace”... wirtualny świat serwisów społecznościowych mortis causa. Zarys problematyki, Wrocławskie Studia Sądowe, 4(4), 234-247.

dr Mateusz Mądel - doktor nauk prawnych, radca prawny. Autor publikacji z zakresu prawa cywilnego, w szczególności prawa zobowiązań i prawa spadkowego. Prowadzi Kancelarię Radcy Prawnego w Tarnowie. 